\title{
O-GIcNAcylation in immunity and inflammation: An intricate system (Review)
}

\author{
$\mathrm{YU} \mathrm{LI}^{1 *}$, MINGZHENG XIE $^{2 *}$, LILI MEN $^{1}$ and JIANLING DU ${ }^{1}$ \\ Departments of ${ }^{1}$ Endocrinology and ${ }^{2}$ General Surgery, The First Affiliated Hospital \\ of Dalian Medical University, Dalian, Liaoning 116011, P.R. China
}

Received February 8, 2019; Accepted June 6, 2019

DOI: $10.3892 /$ ijmm.2019.4238

\begin{abstract}
Chronic, low-grade inflammation associated with obesity and diabetes result from the infiltration of adipose and vascular tissue by immune cells and contributes to cardiovascular complications. Despite an incomplete understanding of the mechanistic underpinnings of immune cell differentiation and inflammation, O-GlcNAcylation, the addition of O-linked $\mathrm{N}$-acetylglucosamine (O-GlcNAc) to cytoplasmic, nuclear and mitochondrial proteins by the two cycling enzymes, the $\mathrm{O}$-linked $\mathrm{N}$-acetylglucosamine transferase (OGT) and the O-GlcNAcase (OGA), may contribute to fine-tune immunity
\end{abstract}

Correspondence to: Dr Jianling Du, Department of Endocrinology, The First Affiliated Hospital of Dalian Medical University, 193 Lianhe Road, Dalian, Liaoning 116011, P.R. China

E-mail: dujianlingcn@163.com

*Contributed equally

Abbreviations: O-GlcNAc, O-linked N-acetylglucosamine; OGT, O-linked $\mathrm{N}$-acetylglucosamine transferase; OGA, O-GlcNAcase; GlcNAc, $\quad \beta$-D-N-acetylglucosamine; UDP-GlcNAc, uridine diphosphate $\mathrm{N}$-acetylglucosamine; HBP, hexosamine biosynthetic pathway; TPR, tetratricopeptide repeat; EGF, epidermal growth factor; AMPK, AMP-activated protein kinase; HAT, histone acetyltransferase; TCR, T cell receptor; Th, T helper; iTregs, inducible regulatory $\mathrm{T}$ cells; IL, interleukin; NF- $\mathrm{KB}$, nuclear factor- $\kappa \mathrm{B}$; I $\kappa \mathrm{B} \alpha$, inhibitor of NF- $\mathrm{B} \alpha$; LPS, lipopolysaccharide; IKK, IкB kinase; CBP, CREB-binding protein; NFAT, nuclear factor of activated $\mathrm{T}$ cells; TNF- $\alpha$, tumor necrosis factor- $\alpha$; TNFAIP3, TNF- $\alpha$ induced protein 3; BCR, B cell receptor; TAK1, transforming growth factor- $\beta$ activated kinase 1; VCAM-1, vascular cell adhesion molecule-1; NO, nitic oxide; iNOS, inducible nitric oxide synthase; STAT3, signal transducer and activator of transcription 3; CUL3, cullin 3; TAB1, TAK1-binding protein 1; GlcN, glucosamine; PUGNAc, O-(2-acetamido-2-deoxy-D-glucopyranosylidene) aminoN-phenylcarbamate; MCAO, middle cerebral artery occlusion; ICAM-1, intercellular adhesion molecule; MPO, myeloperoxidase; GPX1, glutathione peroxidase 1; Glc, Glucose; Fruc, fructose; Nod2, Nucleotide-binding oligomerization domain 2; Sp1, specificity protein 1

Key words: O-GlcNAcylation, O-linked N-acetylglucosamine transferase, O-GlcNAcase, immunity, inflammation and inflammation in both physiological and pathological conditions. Early studies have indicated that O-GlcNAcylation of proteins play a pro-inflammatory role in diabetes and insulin resistance, whereas subsequent studies have demonstrated that this post-translational modification could also be protective against acute injuries. These studies suggest that diverse types of insults result in dynamic changes to O-GlcNAcylation patterns, which fluctuate with cellular metabolism to promote or inhibit inflammation. In this review, the current understanding of O-GlcNAcylation and its adaptive modulation in immune and inflammatory responses is summarized.

\section{Contents}

1. Introduction

2. Enzymes controlling O-GlcNAc cycling

3. Immunoregulatory role of O-GlcNAcylation

4. Pro-inflammatory role of O-GlcNAcylation

5. Anti-inflammatory role of O-GlcNAcylation

6. Conclusions and future perspectives

\section{Introduction}

Over 450 types of protein post-translational modifications have been discovered, including phosphorylation, glycosylation, ubiquitination, acetylation, nitrosylation, methylation and ADP-ribosylation (1). Such modifications dramatically expand the repertoire of potential protein functions and contribute to the high diversity of cellular activities due to their reversible nature, relatively small metabolic cost, and their ability to extensively modulate the functions of target proteins $(2,3)$. Among all post-translational modifications, phosphorylation and glycosylation are considered the most common and the best investigated.

Glycosylation was, until recently, considered a stable and conserved post-translational modification, while phosphorylation was generally considered as a dynamic and reversible modification. A specialized form of O-glycosylation refers to the presence of $\beta$-D-N-acetylglucosamine (GlcNAc) monosaccharide units linked O-glycosidically to intracellular proteins (O-GlcNAcylation). This type of modification was not discovered until 1984 and was found to be directly involved 
in the modulation of a number of cellular processes (4). $\mathrm{O}-\mathrm{GlcNAcylation}$ differs from $\mathrm{N}$-glycosylation and other O-glycosylation like O-GalNAcylation by occurring mainly on nuclear, cytoplasmic and mitochondrial proteins, and by being temporally dynamic. Unlike $\mathrm{N}$-glycosylation, O-GlcNAcylation is more analogous to phosphorylation as it occurs rapidly and reversibly. Interestingly, O-GlcNAcylation can either compete or co-operate with phosphorylation since it targets either the same or the proximal serine/threonine (Ser/Thr) residue sites required for phosphorylation (5). However, unlike phosphorylation that is regulated by a diverse array of kinases and phosphatases, O-GlcNAcylation is controlled by the action of a single pair of enzymes, OGT and OGA (6). OGT is the specific enzyme responsible for catalyzing the reaction between a single GlcNAc moiety and the hydroxyl group of a ser or thr residue on proteins, while OGA is the specific glycoside hydrolase that removes it $(6,7)$. The substrate of the transferase reaction is uridine diphosphate $\mathrm{N}$-acetylglucosamine (UDP-GlcNAc), which is synthesized by the hexosamine biosynthetic pathway (HBP). HBP co-ordinates with almost every other metabolic cellular pathway since O-GlcNAcylation is sensitive to the levels of insulin, glucose, amino acids (glutamine), fatty acid (acetyl-CoA), nucleotide (UDP) and cellular stress. Therefore, O-GlcNAcylation has mainly been considered to serve in the regulation of cellular signaling, transcription and translation in response to nutrients and stresses (8) (Fig. 1). Signaling pathways convert environmental cues into intracellular events, such as immune cell activation and inflammation. Combined aberrant O-GlcNAcylation may be the cause of excessive nutrient intake, diabetes and/or autoimmune diseases progressions, including those involved in inflammatory and immune responses in individual cell types and tissues (Table I).

\section{Enzymes controlling O-GIcNAc cycling}

$O$-linked $N$-acetylglucosamine transferase (OGT). OGT is encoded by a single gene in mammals, however, its transcript produces multiple variants after selective splicing which are as follows: Nucleocytoplasmic, (ncOGT; $116 \mathrm{kDa}$ ); mitochondrial, (mOGT; $103 \mathrm{kDa}$ ) and short, (sOGT; $78 \mathrm{kDa}$ ) (9). They share a common catalytic and phosphorylase-derived C-terminal domain but differ in length owing to variable numbers of the N-terminal tetratricopeptide repeat (TPR) domain (10), separated by a spacer region. It had long been believed that OGT isoforms are present in the cytoplasm and nucleus, such as ncOGT and sOGT; and in mitochondria, such as mOGT (7). However, an atypical OGT termed epidermal growth factor domain-specific O-GlcNAc transferase (EOGT) was identified, which transfers GlcNAc to Ser or Thr in secreted and membrane proteins containing the epidermal growth factor (EGF) repeat with a specific consensus sequence. Interestingly, OGT and EOGT exist in separate cellular compartments and have mostly distinct substrates $(11,12)$.

OGT modulates a variety of cellular processes like transcription, protein synthesis $(9)$, protein degradation $(13,14)$, protein-protein interaction or localization $(7,15,16)$ and stress response (17) using several substrates. However, it has been difficult to elucidate the mechanisms by which OGT recognizes its substrates since it targets only a fraction of Ser/Thr in different biological situations for glycosylation. There have been several suggested potential mechanisms. OGT primarily recognizes most of its substrates through asparagine ladder binding in the TPR domain $(18,19)$. The interaction between OGT and its substrates also contributes to the OGT catalytic mechanism. The N-acyl group in UDP-GlcNAc is crucial for its affinity to sOGT. In this process, the backbone carbonyl oxygen of L653 and the hydroxyl group of T560 in sOGT are important for the recognition of the UDP-GlcNAc (20). Additionally, OGT can also non-specifically modify proteins which contain regions of intrinsic disorder (e.g. tau and nuclear pore proteins) without recognizing any specific sequences or structures (7). Different UDP-GlcNAc concentrations or varying UDP-GlcNAc gradients may influence OGT binding specificity (21). Finally, OGT is also regulated by phosphorylation. The phosphorylation of OGT at T444 by AMP-activated protein kinase (AMPK) is closely associated with OGT nuclear localization in myotubes and phospho-mimetic T444E-OGT exhibits altered substrate selectivity. Acute treatment $(2 \mathrm{~h})$ with a highly specific activator of AMPK (A-769662) induced significant global changes in O-GlcNAcylated proteins bound to wild-type OGT compared with T444E-ncOGT. It demonstrated the placement of a large highly charged moiety on residue T444 is sufficient to dramatically alter the substrate selectivity of OGT (22).

Genetic and chemical approaches are used to inhibit both OGT expression and activity to comprehensively study the biological role of O-GlcNAc and assess the catalytic vs. non-catalytic roles of OGT. Complete OGT knockout is embryo-lethal in a range of animal models. As such, tissue-specific OGT knockout mice have been employed (23). Consequently, chemical inhibitors are a worthwhile means to explore the biological role of O-GlcNAcylation without affecting OGT protein levels. UDP, alloxan, compound 4 (ST045849), compound 5 and $(\alpha \mathrm{R})-\alpha-[[(1,2-\mathrm{Dihydro}-2$-oxo-6-quinolinyl)sulfonyl] amino]-N-(2-furanylmethyl)-2-methoxy-N-(2-hienylmethyl)benzeneacetamide are small molecules that compete with the donor substrate (24-26) (Fig. 1). In addition, a new series of competitive inhibitors, goblin1 (OGT bisubstrate-linked inhibitor 1) and goblin 2, derived from both OGT and the substrate, were designed based on the understanding of the OGT catalytic mechanism (27). However, off-target effects, lack of specificity and low-grade cell permeability are limitations that need to be resolved (28).

$O$-GlcNAcase (OGA). The human OGA (hOGA) gene MGEA5 is alternatively spliced to generate nucleocytoplasmic (nc; $130 \mathrm{kDa}$ ) and short (s; $75 \mathrm{kDa}$ ) isoforms. The ncOGA contains both an N-terminal O-GlcNAc hydrolase and a C-terminal histone acetyltransferase-like (HAT-like) domain; while sOGA lacks the HAT-like domain and is localized to the endoplasmic reticulum and lipid droplets $(29,30)$.

hOGA belongs to the carbohydrate-active enzymes database glycoside hydrolase 84 family of enzymes (31). The substrate recognition mechanism of hOGA was not considered to be sequence specific until the crystal structure for hOGA was reported (32). The crystallographic data for hOGA suggested that the full-length and nuclear spliced isoforms could be structurally distinguished by 


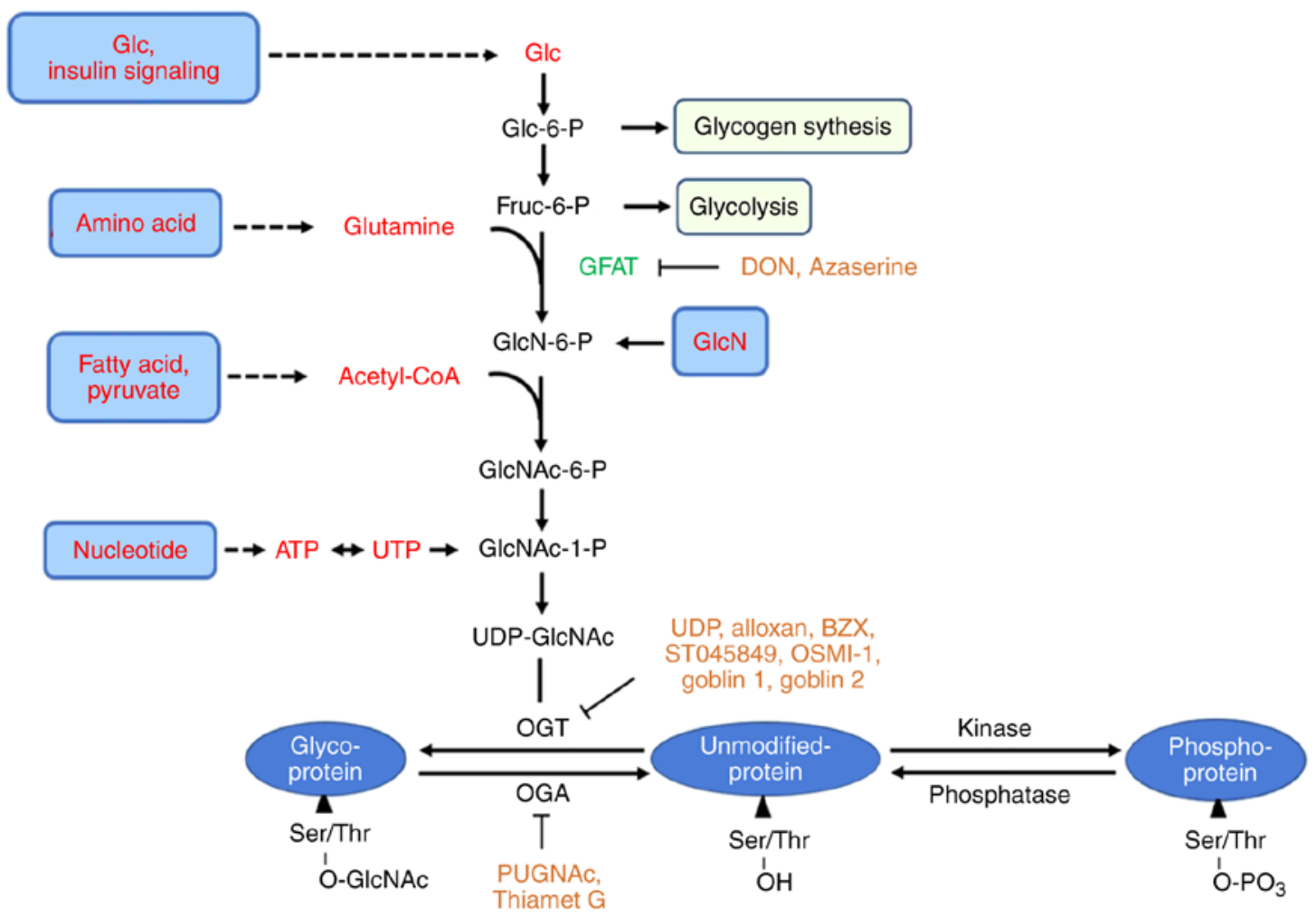

Figure 1. Nutrient flux through the HBP modulates protein O-GlcNAcylation. The majority of glucose is taken for glycolysis and glycogen synthesis, but a small percentage $(\sim 2-5 \%)$ is funneled directly into the HBP for UDP-GlcNAc synthesis. OGT catalyzes the addition of GlcNAc from UDP-GlcNAc to serine and threonine residues, while OGA catalyzes their removal. Together these two enzymes tune the dynamic addition and removal of O-GlcNAc for thousands of diverse proteins. O-GlcNAcylation sites are usually directly at, or close to, the same serine or threonine residues used by kinases. HBP, hexosamine biosynthetic pathway; OGT, O-linked N-acetylglucosamine transferase; OGA, O-GlcNAcase; GlcNAc, N-acetylglucosamine; UDP, uridine diphosphate; GFAT, glutamine-fructose-6-phosphate aminotransferase; OSMI-1, $(\alpha \mathrm{R})-\alpha$-[[(1,2-Dihydro-2-oxo-6-quinolinyl)sulfonyl]amino]-N-(2-furanylmethyl)-2-methoxy$\mathrm{N}$-(2-thienylmethyl)-benzeneacetamide.

their ability to form an interlinked dimer. Based on the crystal structure, novel inhibitors targeting hOGA other than O-(2-acetamido-2-deoxy-D-glucopyranosylidene) amino-N-phenylcarbamate (PUGNAc) and thiamet G could be designed $(32,33)$ (Fig. 1). Notably, OGA can be O-GlcNAcylated by OGT at S405; however, the implications of O-GlcNAcylation of OGA have remained elusive $(1,34)$.

\section{Immunoregulatory role of O-GlcNAcylation}

O-GlcNAcylation activates T cells. The T cell receptor (TCR) is a molecule present on the surface of $\mathrm{T}$ cells that is responsible for recognizing antigens as peptides which are bound to major histocompatibility complex II molecules on the surface of antigen presenting cells. This triggers the initial activation of cluster of differentiation (CD) $4^{+} \mathrm{T}$ cells (35) and directs $\mathrm{CD} 4^{+} \mathrm{T}$ cell differentiation into four effectors: $\mathrm{T}$ helper 1 (Th1), which target intracellular bacteria and viruses; Th2, which target extracellular parasites; Th17, which target fungi and extracellular pathogens and inducible regulatory $\mathrm{T}$ cells (iTregs), which have the opposing function of decreasing an inflammatory immune response. $T$ cell activation induces expression of GLUT1 and amino acid transporters on the cell surface which transport adequate glucose and glutamine for the differentiation of Th1, Th2 and Th17 cells. Moreover, the conversion of glutamine to acetyl CoA boosts fatty acid synthesis during $\mathrm{T}$ cell activation $(36,37)$. Taken together, glucose, glutamine and acetyl CoA are all substrates that participate in the HBP, driving an increase in UDP-GlcNAc synthesis and thus protein O-GlcNAcylation by OGT $(37,38)$ (Fig. 2).

$\mathrm{T}$ cell activation enhances both OGT expression and overall protein O-GlcNAylation levels. More than 2,000 intact O-linked glycopeptides have been identified on activated primary human $\mathrm{T}$ cells via a technique termed as isotope targeted glycoproteomics. A large portion $(>45 \%)$ of identified O-GlcNAc sites lie in proximity to or coincide with a known phosphorylation site, indicating a possibility of post-translational modification crosstalk (39). It has been reported that deficiency in protein O-GlcNAcylation results in the blocking of $\mathrm{T}$ cell proliferation, development, transformation and differentiation $(40,41)$. Importantly, Notch, TCR and c-Myc (T58) have been identified as key controllers of $\mathrm{T}$ cell protein $\mathrm{O}-\mathrm{GlcN}$ Acylation by regulation of glucose and glutamine transport $(41,42)$.

The nuclear factor $(\mathrm{NF})-\kappa \mathrm{B}$ transcription factor family consists of five proteins, including p65 (RelA), RelB, c-Rel,

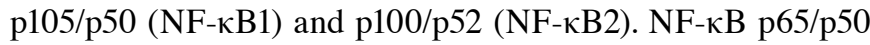
is the most commonly occurring heterodimer complex among $\mathrm{NF}-\kappa \mathrm{B}$ homodimers and heterodimers and is the functional component involved in nuclear translocation and activation of $\mathrm{NF}-\kappa \mathrm{B}$ (43). Under quiescent conditions, the inactive $\mathrm{NF}-\kappa \mathrm{B}$ p65/p50 heterodimer is mainly sequestered in the cytoplasm and is associated with inhibitor of $\mathrm{NF}_{-} \kappa \mathrm{B} \alpha(\mathrm{I} \kappa \mathrm{B} \alpha)$. However, 
Table I. Functions of O-GlcNAcylation in immune and inflammatory responses.

\begin{tabular}{|c|c|c|c|c|c|}
\hline Author, year & $\begin{array}{l}\text { Cell type } \\
\text { and tissue }\end{array}$ & $\begin{array}{l}\text { Stimuli and } \\
\text { treatment }\end{array}$ & $\begin{array}{c}\text { Target protein and } \\
\text { O-GlcNAcylation site }\end{array}$ & Function & (Refs.) \\
\hline $\begin{array}{l}\text { Golks et al, 2007; } \\
\text { Lund et al, 2016; } \\
\text { Bunting et al, 2007; } \\
\text { Swamy et al, } 2016\end{array}$ & $\mathrm{~T}$ cells & Anti-CD3/CD28 Ab & $\begin{array}{l}\text { NFAT, p65, } \\
\text { c-Rel (S350) } \\
\text { c-Myc (T58) }\end{array}$ & $\begin{array}{l}\text { T cell activation, } \\
\text { IL- } 2, \text { IFNG, and CSF } 2 \uparrow \\
\text { T cell clonal expansion }\end{array}$ & $\begin{array}{l}(52) \\
(40) \\
(53) \\
(41)\end{array}$ \\
\hline $\begin{array}{l}\text { Golks et al, 2007; } \\
\text { Wu et al, } 2017\end{array}$ & B cells & $\begin{array}{l}\text { Anti-IgM Ab } \\
-\end{array}$ & NFAT, p65 Lyn (S19) & $\begin{array}{l}\text { B cell activation } \\
\text { B-cell activation } \\
\text { and expansion }\end{array}$ & $\begin{array}{l}(52) \\
(56)\end{array}$ \\
\hline $\begin{array}{l}\text { Kneass and } \\
\text { Marchase, 2005; } \\
\text { Kneass and } \\
\text { Marchase, } 2004\end{array}$ & Neutrophils & fMLF/PMA & - & Cellular migration & $\begin{array}{l}(66) \\
(67)\end{array}$ \\
\hline James et al, 2002 & Mesangial cells & High glucose, GlcN & p65 & VCAM-1 $\uparrow$ & (73) \\
\hline Dela et al, 2017 & Placentas cells & High glucose & p65 & TNF- $\alpha$ and IL- $6 \uparrow$ & (74) \\
\hline $\begin{array}{l}\text { Krick et al, } 2018 \\
\text { Donovan et al, } 2014\end{array}$ & Epithelial cells & $\begin{array}{l}\text { FGF23 } \\
\text { high glucose }\end{array}$ & Sp1 - & $\begin{array}{l}\text { NFAT activation } \uparrow \text { IL- } 6 \uparrow \\
\text { VEGF-A } \uparrow\end{array}$ & $\begin{array}{l}(71) \\
(81)\end{array}$ \\
\hline Zhang et al, 2015 & $\begin{array}{l}\text { Pancreatic acinar } \\
\text { cells }\end{array}$ & caerulein & $\mathrm{p} 65, \mathrm{IKK} \alpha$ & TNF- $\alpha$ and NO $\uparrow$ & (75) \\
\hline $\begin{array}{l}\text { Li et al, 2014; } \\
\text { Donovan et al, 2014; } \\
\text { Zhang et al, } 2017\end{array}$ & Endothelial cells & $\begin{array}{l}\text { LPS } \\
\text { High glucose }\end{array}$ & $\begin{array}{l}\text { p65 } \\
\text { Sp1 }\end{array}$ & $\begin{array}{l}\text { Inflammatory mediators } \uparrow \\
\text { VEGF-A, ICAM- } 1 \uparrow\end{array}$ & $\begin{array}{c}(76) \\
(81,82)\end{array}$ \\
\hline $\begin{array}{l}\text { Allison et al, 2012; } \\
\text { Ma et al, 2017; }\end{array}$ & $293 \mathrm{~T}$ & TNF- $\alpha$ & p65 (T305, S319) & IL-6 and TNF- $\alpha \uparrow$ & $\begin{array}{l}(78,79) \\
(85,88)\end{array}$ \\
\hline Hou et al, 2016 & & MDP & Nod 2 & $\mathrm{NF}-\kappa \mathrm{B}$ activity $\uparrow$ & \\
\hline $\begin{array}{l}\text { Hwang et al, 2017; } \\
\text { Ryu and Do, 2011; } \\
\text { Li et al, 2017; } \\
\text { Pathak et al,2012; } \\
\text { Zhang et al, } 2016\end{array}$ & Macrophages & $\begin{array}{l}\text { LPS IL-1/osmotic } \\
\text { stress }\end{array}$ & $\begin{array}{l}\text { STAT3(T717) } \\
\text { TAK1(S427) }\end{array}$ & $\begin{array}{l}\text { NO/iNOS } \uparrow ; \\
\text { IL-12, CXCL1 and } \\
\text { CXCL2 } \uparrow ; \text { IL-10 } \downarrow \text {; } \\
\text { polarization }\end{array}$ & $(62,63,8485,87)$ \\
\hline $\begin{array}{l}\text { Hwang et al, 2010; } \\
\text { Hwang et al, } 2014\end{array}$ & $\begin{array}{l}\text { Macrophages smooth } \\
\text { Muscle cells }\end{array}$ & GlcN with LPS & $\begin{array}{l}\text { p65 and c-Rel, } \\
\text { RNAPII }\end{array}$ & $\begin{array}{l}\text { COX-2, iNOS, IL-1 } \beta \text {, } \\
\text { IL-6, TNF- } \alpha \downarrow\end{array}$ & $(64,65)$ \\
\hline He et al, 2017 & & $\begin{array}{l}\text { Thiamet G with } \\
\text { MCAO or LPS }\end{array}$ & - & $\begin{array}{l}\text { Iba+ cells } \downarrow \text { iNOS } \\
\text { and COX2 } \downarrow \text { p65 } \\
\text { translocation } \downarrow \text { M1 } \\
\text { polarization } \downarrow\end{array}$ & (103) \\
\hline Yang et al, 2008 & & High glucose & p65 (T352) & VCAM-1 $\uparrow$ & (77) \\
\hline Yang et al, 2010; & Smooth muscle cells & High glucose & PGX1 p65 (S536), & anti-oxidant activity $\uparrow$ & $(112)$ \\
\hline $\begin{array}{l}\text { Xing et al, } 2011 ; \\
\text { Yao et al, } 2018\end{array}$ & Colon epithelial cell & $\begin{array}{l}\text { GlcN/OGA inhibitor } \\
\text { with TNF- } \alpha\end{array}$ & A20 & $\begin{array}{l}\text { MCP-1, P-selectin, } \\
\text { VCAM- } 1 \downarrow\end{array}$ & $(98,111)$ \\
\hline Hirata et al, 2018 & & $\begin{array}{l}\text { dextran sodium } \\
\text { sulfate }\end{array}$ & - & $\begin{array}{l}\text { phosphor-p65 } \downarrow \\
\text { IL-1 } \beta \downarrow\end{array}$ & (99) \\
\hline Zou et al, 2007 & Heart & $\begin{array}{l}\text { GlcN with trauma- } \\
\text { hemorrhage }\end{array}$ & - & $\begin{array}{l}\text { cardiac output and organ } \\
\text { perfusion recovered }\end{array}$ & (91) \\
\hline Guo et al, 2015 & Heart & $\begin{array}{l}\text { Intermittent } \\
\text { hypoxia }\end{array}$ & - & $\begin{array}{l}\text { MAPK activity } \uparrow \text { p65 } \\
\text { levels } \uparrow \text { inflammatory } \\
\text { mediators } \uparrow\end{array}$ & (72) \\
\hline
\end{tabular}

IL, interleukin; LPS, lipopolysaccharide; IKK, IKB kinase; NFAT, nuclear factor of activated T cells; TNF- $\alpha$, tumor necrosis factor- $\alpha$; TAK1, transforming growth factor- $\beta$ activated kinase 1 ; VCAM-1, vascular cell adhesion molecule-1; NO, nitic oxide; iNOS, inducible nitric oxide synthase; STAT3, signal transducer and activator of transcription 3; TAB1, TAK1-binding protein 1; GlcN, glucosamine; MCAO, middle cerebral artery occlusion; ICAM-1, intercellular adhesion molecule; MPO, myeloperoxidase; FGF23, fibroblast growth factor 23; Nod2, Neucleotide-binding oligomerization domain 2; Sp1, specificity protein 1 . 


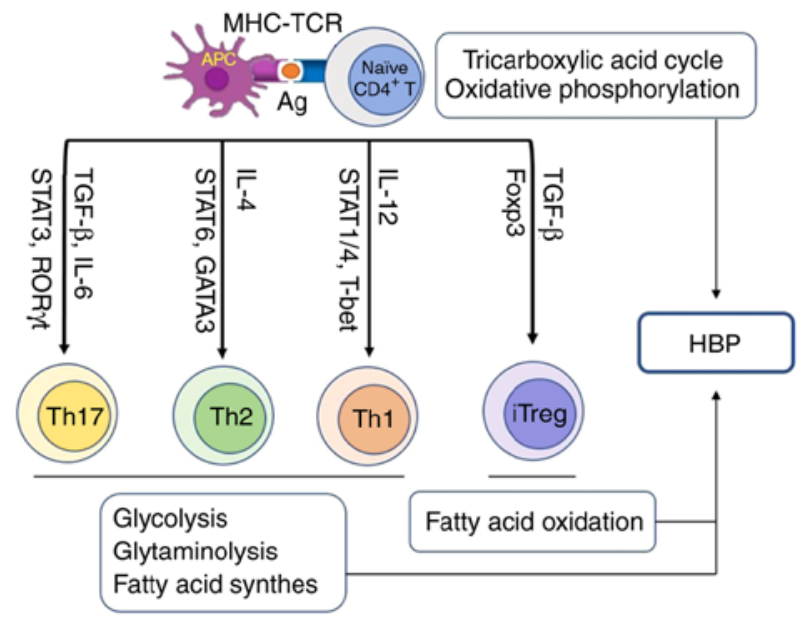

Figure 2. Connection between helper $\mathrm{T}$ cell differentiation and HBP. After $\mathrm{T}$ cell antigen receptor engagement, naïve $\mathrm{CD} 4^{+} \mathrm{T}$ cells differentiate into effector T cells including Th1, Th2 and Th17 cells, as well as iTreg. Effector T cells utilize glucose through glycolysis and amino acids through glutaminolysis to meet their energy need for differentiation, whereas regulatory $\mathrm{T}$ cells use energy from fatty acid oxidation. Finally, HBP integrates glucose, amino acid and fatty acid metabolism to generate UDP-GlcNAc for O-GlcNAc modification. CD, cluster of differentiation; HBP, hexosamine biosynthetic pathway; iTregs, inducible regulatory T cells; MHC, major histocompatibility complex; TCR, T cell receptor; IL, interleukin; UDP-GlcNAc, uridine diphosphate $\mathrm{N}$-acetylglucosamine; APC, antigen presenting cell.

upon stimulation by pro-inflammatory cytokines, lipopolysaccharide (LPS) or glucose, I $\mathrm{I} \mathrm{B} \alpha$ is phosphorylated by the I $\mathrm{B}$ kinase (IKK) on S32 and S36. This phosphorylation results in $\mathrm{I} \kappa \mathrm{B}$ ubiquitination and subsequent degradation by the $26 \mathrm{~S}$ proteasome. NF- $\kappa \mathrm{B}$ p $65 / \mathrm{p} 50$ then detaches from I $\kappa \mathrm{B} \alpha$ and translocates to the nucleus where it binds to $\mathrm{NF}-\kappa \mathrm{B}$ promoter/enhancer sites. Through its acidic transactivation domain, p65 has the capacity to interact with several different transcriptional regulatory proteins, such as CREB-binding protein $(\mathrm{CBP}) / \mathrm{p} 300$, to initiate transcription of $\mathrm{NF}-\kappa \mathrm{B}$ target genes $(44,45)$. NF- $\kappa \mathrm{B}$ is primarily modulated by post-translational modifications, such as phosphorylation, acetylation and glycosylation. It regulates several cellular processes like innate immunity, adaptive immunity, inflammation, cell apoptosis, cell survival and differentiation. The activity of NF- $\kappa \mathrm{B}$ is closely associated with the pathogenesis of metabolic syndrome (46). Metabolic syndrome comprises hyperglycemia, hyperlipidemia, insulin resistance, obesity and hepatic steatosis which result from nutrient excess (47). Mounting an immune response to infection resulting in the release of cytokines is energy intensive. $N F-\kappa B$ is activated by cytokines to promote re-localization, activation and differentiation of macrophages at the site of infection. These activated macrophages defend against invading microorganisms by producing antimicrobial molecules and recruiting leukocytes, subsequently removing pathogens and clearing dead cells $(48,49)$. NF- $\kappa$ B-regulated expression of the inflammatory mediators drives the differentiation of monocytes into either M1 or M2 macrophages which are vital to the development of the inflammation-associated metabolic disease. M1 macrophages produce and release IL-1, IL-6, tumor necrosis factor (TNF)- $\alpha$, and other pro-inflammatory cytokines, while M2 macrophages secrete the anti-inflammatory cytokine
IL-10 $(49,50)$. Therefore, NF- $\mathrm{B}$ controls the expression of the inflammatory mediators that recruit monocytes, drive differentiation to macrophages and direct macrophage cell fate. $\mathrm{NF}-\kappa \mathrm{B}$ therefore modulates inflammation in the liver, adipose tissue and central nervous system in the development of metabolic diseases $(49,51)$. Furthermore, an increase in NF- $\kappa \mathrm{B}$ p65 $\mathrm{O}-$ GlcNAcylation contributes to $\mathrm{T}$ cell activation. It has been reported that OGT is required for the O-GlcNAcylation and transcriptional activity of both p65 as well as nuclear factor of activated T cells (NFAT). This leads to IL-2 production which is consistent with $\mathrm{T}$ cell activation (52). Additionally, NF- $\kappa \mathrm{B}$ subunit c-Rel is modified and activated by O-GlcNAcylation at S350. Conversely, mitigating the O-GlcNAcylation of this residue disturbs the c-Rel-mediated expression of IL-2, IFN- $\gamma$ and colony stimulating factor (CSF) 2 in response to TCR activation. However, mutating the O-GlcNAcylation site of c-Rel or treating cells with PUGNAc has no effect on TCR or TNF- $\alpha$ induced expression of TNFAIP3 (encodes TNF- $\alpha$ induced protein 3) and NFKBIA (encodes NF- $\mathrm{B}$ inhibitor $\alpha$ ), genes that are considered to contain c-Rel binding sites in their promoters (53). Although TCR and TNF both elevate the nuclear translocation of c-Rel, only TCR activity resulted in the O-GlcNAcylation of c-Rel in the nucleus. These results suggest a stimulus-specific role or O-GlcNAcylation of c-Rel in promoting $\mathrm{T}$ cell-mediated autoimmunity. It is the generation of these autoimmune $\mathrm{T}$ helper cell cytokines which result in pancreatic $\beta$-cell injury leading to type 1 diabetes $(54,55)$.

$O$-GlcNAcylation activates B-cells. B cell activation, like $\mathrm{T}$ cell activation, is triggered by the specific recognition of antigens by the $\mathrm{B}$ cell receptor (BCR). In activated B cells, $\mathrm{NF}-\kappa \mathrm{B}$ and NFAT are O-GlcNAcylated by OGT through direct interaction and this correlates strongly with their translocation to the nucleus (52). Intriguingly, O-GlcNAcylation of Lyn at S19 is critical for Lyn activation and Syk interaction in BCR-mediated B-cell activation and expansion (56). Taken together, O-GlcNAcylation mediated by OGT contributes to maintain homeostasis, transduce BCR-mediated activation signals and activate humoral immunity.

O-GlcNAcylation modulates the activation of monocytes and macrophages. Monocytes and macrophages play vital roles in acute and chronic inflammation. Obesity, diabetes and insulin resistance are concomitant with the aggregation of pro-inflammatory monocytes and macrophages in different organs, such as the pancreas, adipose tissue, liver and blood vessel walls (57-61). O-GlcNAcylation is implicated in the inflammatory reaction in monocytes and macrophages, such as c-Rel. At normal glucose concentrations, glucosamine (GlcN) dose-dependently increases LPS-stimulated c-Rel $\mathrm{O}-\mathrm{GlcNAcylation}$ and production of $\mathrm{NO} /$ inducible nitric oxide synthase $(6,62)$. Of interest, OGT de-nitrosylation is triggered by LPS in macrophage cells and results in p62 and p65 hyper-O-GlcNAcylation and $\mathrm{NO}$ /cytokine production. As mentioned previously, this study supports a role for de-nitrosylation of S-nitrosylated OGT in controlling the LPS-stimulated innate immune response due to upregulation of OGT activity (63).

Numerous previous studies $(64,65)$, on the other hand, indicate that O-GlcNAcylation participates in anti-inflammatory 
responses in monocytes and macrophages and have tried to uncover the mechanisms by which O-GlcNAcylation protects monocytes and macrophages from inflammatory stresses. GlcN may serve as a novel neuroprotective or anti-inflammatory agent, not only because it reduces infarct volume and affords a reduction in motor impairment and neurological deficits in a rat middle cerebral artery occlusion model, but also because it suppresses LPS-induced upregulation of pro-inflammatory mediators both in microglia (BV2) and macrophages (RAW264.7) (64). GlcN is a substrate for glutamine: Fructose-6-phosphate amidotransferase (GFAT), the rate-limiting enzyme in the HBP. Thus, when the glucose and glutamine influx rapidly increases, UDP-GlcNAc levels and subsequent O-GlcNAcylation can also rise. However, in this case, GlcN inhibits the O-GlcNAcylation of $\mathrm{NF}-\kappa \mathrm{B}$, probably by disturbing the association between OGT and $\mathrm{NF}-\kappa \mathrm{B}(64)$.

O-GlcNAcylation activates neutrophils. Neutrophils (polymorphonuclear leukocytes) are a key member of the innate immune system and are activated when presented with a large and diverse group of stimuli. The process of activation initiates a cascade of events that lead to spreading and finally migration. It has been reported that O-GlcNAcylation mediates the activation of the small GTPase Rac and the downstream p38 and p44/42 mitogen-activated protein kinase (MAPK) signaling pathways in neutrophils. These MAPKs are known to modulate cellular chemotaxis leading to cell movement and inflammatory response (66-68).

\section{Pro-inflammatory role of O-GlcNAcylation}

Positive regulation of the transcription factors by $O$-GlcNAcylation. A total of $\sim 4,000$ proteins have been identified as OGT targets to-date and this will continue to increase as the technology for mapping and quantifying O-GlcNAc sites improves (69,70). O-GlcNAcylation affects $\mathrm{NF}-\kappa \mathrm{B}, \mathrm{NFAT}$ and specificity protein 1 (Sp1) which are related to inflammation and immune reactions. For example, fibroblast growth factor 23 augments the global changes in the O-GlcNAc modification of proteins in human bronchial epithelial cells to regulate airway inflammation through NFAT activation and IL-6 upregulation (71). Intermittent hypoxia raises the O-GlcNAc in proteins, accompanied by an increase in the levels of myocardial NF- $\mathrm{B}$, inflammatory cytokines, caspase- 3 and cardiomyocyte apoptosis (72).

The most widely and intensively studied O-GlcNAcylated transcription factor is $\mathrm{NF}-\kappa \mathrm{B}$ (7). High glucose and pro-inflammatory factors, risks for metabolic syndrome and diabetes mellitus are deemed to activate the $\mathrm{NF}-\kappa \mathrm{B}$ pathway and initiate the transcription of relevant downstream target genes. Therefore, the role of O-GlcNAcylation in $\mathrm{NF}-\kappa \mathrm{B}$ activation has gained more attention.

It has been reported that glucosamine, high glucose and overexpression of GFAT are employed to prompt the binding between nuclear proteins and $\mathrm{NF}-\kappa \mathrm{B}$ consensus sequences. This enhances vascular cell adhesion molecule-1 (Vcam-1) promoter activity in glomerulus cells isolated from male Sprague-Dawley rats (73). This set of data suggest that NF- $\kappa \mathrm{B}$ O-GlcNAcylation can participate in inflammation (73).
Furthermore, high glucose has been found to augment $\mathrm{O}-\mathrm{GlcNAcylation}$ of $\mathrm{NF}-\kappa \mathrm{B}$ and production of cytokines TNF- $\alpha$ and IL-6 in rat placenta (74). However, little is known about the mechanisms through which O-GlcNAcylation upregulates $\mathrm{NF}-\kappa \mathrm{B}$ activity. In the caerulein-stimulated acute pancreatitis model, OGT-mediated O-GlcNAcylation of NF- $\kappa \mathrm{B}$ p 65 and IKK $\alpha$ promotes NF- $\mathrm{BB}$ signaling activation, TNF- $\alpha$ secretion and nitric oxide (NO) production in AR42 $\mathrm{J}$ rat pancreatic acinar cells which might exacerbate the progression of acute pancreatitis (75). In addition, the authors' previous study has confirmed that LPS triggers the OGT-dependent O-GlcNAcylation of NF- $\mathrm{B}$ and thereby induces a vascular endothelial inflammatory response (76). However, the O-GlcNAc modification sites on NF-kB have not been confirmed and the mechanism by which O-GlcNAc modification promotes NF-kB activation has not been completely elucidated.

An increasing amount of research is focused today on demonstrating the pro-inflammatory role of O-GlcNAcylation in the NF- $\mathrm{NB}$ signaling pathway. In rat vascular smooth muscles, O-GlcNAcylation of NF- $\mathrm{B}$ p 65 on T352 inhibits the interaction between $\mathrm{NF}-\kappa \mathrm{B}$ p 65 and $\mathrm{I} \kappa \mathrm{B}$, thus elevating the translocation of NF- $\kappa \mathrm{B}$ to the nucleus and increasing the transcription of VCAM-1 under hyperglycemic conditions (77). These results suggest that a specific O-GlcNAcylation site at $\mathrm{T} 352$ on $\mathrm{NF}-\kappa \mathrm{B}$ p65 may contribute to a prolonged increase in NF- $\kappa \mathrm{B}$ activity during the progression of diabetes (77). Moreover, the transcriptional activity of $\mathrm{NF}-\kappa \mathrm{B}$ seems to increase its concomitant phosphorylation and acetylation, which may interact with O-GlcNAcylation in $293 \mathrm{~T}$ cells $(78,79)$. Under the stimulation of TNF- $\alpha$, OGT enhances the $\mathrm{CBP} / \mathrm{p} 300$-dependent acetylation of NF- $\mathrm{NB}$ p65 on K310 by combining with $\mathrm{NF}-\kappa \mathrm{B}$ regulated promoters and subsequently promotes full $\mathrm{NF}-\kappa \mathrm{B}$ transcription. Previous mapping studies reveal $\mathrm{T} 305$ to be an important residue required for attachment of the O-GlcNAc moiety on p65 $(78,79)$. Similarly, Ma et al (79) have verified that O-GlcNAcylation of p65 on T305 and S319 increases CBP/p300-dependent acetylation of p65 on $\mathrm{K} 310$, facilitating $\mathrm{NF}-\kappa \mathrm{B}$ transcriptional activation. In addition to enhancing O-GlcNAcylation, OGT increases the expression of $\mathrm{p} 300$, IKK $\alpha$ and $\operatorname{IKK} \beta$, and elevates IKK-induced p65 phosphorylation on S536, leading to NF- $\kappa \mathrm{B}$ activation. However, O-GlcNAcylation of p65 at T305 is likely impaired by the phosphorylation of p65 at T308 (79). In addition, O-GlcNAcylation of IKK $\beta$ occurring at S733 has been discovered to prompt the $\mathrm{NF}-\kappa \mathrm{B}$ activity by heightening IKK activity, $\mathrm{I} \kappa \mathrm{B}$ phosphorylation and $\mathrm{I} \kappa \mathrm{B}$ degradation in cultured mouse and human fibroblasts (80).

$\mathrm{Sp} 1$, another transcription factor, besides $\mathrm{NF}-\kappa \mathrm{B}$, is also O-GlcNAcylated under high glucose concentration. Donovan et al (81) indicated that hyperglycemia significantly increases the binding of $\mathrm{Sp} 1$ to the vascular endothelial growth factor (VEGF)-A promoter, while the downregulation of OGT or Sp1 by shRNA significantly abro gates glucose-induced changes in proangiogenic protein VEGF-A in ARPE-19 (human retinal pigment epithelial cells) and TR-iBRB (rat retinal microendothelial cells). This suggests that hyperglycemia-driven elevation of O-GlcNAcyaltion of Sp1 mediates VEGF-A production in the retinal endothelium and pigment epithelium. Furthermore, Zhang et al (82) confirmed that 
hyperglycemia also stimulated intercellular adhesion molecule (ICAM)-1 expression by O-GlcNAc modification of Sp1 in human umbilical vein endothelial cells and rat retinal capillary endothelial cells. Taken together, this group of studies helps to enhance understanding of how O-GlcNAcylation modulates inflammatory factors during diabetic retinopathy.

Signal transducer and activator of transcription 3 (STAT3) plays a key role in the cytokine-cytokine receptor signaling pathway in colitis (83). Nevertheless, the critical mechanism that regulates STAT3 phosphorylation and its target pro-inflammatory cytokine production remains unclear. Li et al (84) demonstrated that modification of STAT3 with O-GlcNAc at T717 suppresses its phosphorylation and the expression of the downstream anti-inflammatory gene, IL-10, in bone marrow-derived macrophages (BMMs) isolated from cullin $(\mathrm{Cul})$ 3-deficient mice led to increased disease severity in azoxymethane (AOM) induced colitis and a colitis-associated cancer model. Meanwhile, the expression of pro-inflammatory cytokines, such as IL-12, CXCL1 and CXCL2 are upregulated by O-GlcNAcylated STAT3 in BMMs generated from $\mathrm{Cul} 3$-deficient mice make them more susceptible to AOM-induced colitis and colitis-associated cancer. Furthermore, the researchers found that myeloid-derived CUL3, a cullin family E3 ubiquitin ligase, attenuated OGT expression and downregulated STAT3 O-GlcNAc modification by facilitating the interaction between the $O g t$ promoter region and nuclear factor-erythroid-2 related transcription factor-2. The depletion of STAT3 O-GlcNAcylation mediated by CUL3 is concomitant with the upregulation of STAT3 phosphorylation and IL-10 gene expression.

Pro-inflammatory effects of other O-GlcNAcylated proteins. In addition to transcription factors, other functional proteins are found to be O-GlcNAcylated in pro-inflammatory reaction. Transforming growth factor- $\beta$ activated kinase (TAK) 1 is an important serine/threonine protein kinase that mediates signals transduced by pro-inflammatory cytokines such as TGF- $\beta$, TNF- $\alpha$ and IL-1. A number of experimental data suggest that O-GlcNAcylation of TAK1-binding protein 1 (TAB1) at S395 is required for full TAK1 activation upon stimulation with IL-1/osmotic stress, for the downstream activation of NF- $\mathrm{BB}$ and finally for the production of IL- 6 and TNF- $\alpha$ in IL-1R cells 293 (cells stably expressing the IL-1 receptor) and immortalized Tabl-deficient MEFs (85). Another study indicated that TAK1 is O-GlcNAcylated as well. Upon stimulation with IL-1 and $\mathrm{NaCl}, \mathrm{O}-\mathrm{GlcNAcylation}$ of TAK1 at S427 is required for T187/S192 phosphorylation and full activation of TAK1 in RAW264.7 cells (86). Thus, TAK1 O-GlcNAcylation has been found to activate downstream JNK and NF- $\kappa \mathrm{B}$ signaling pathways and increase pro-inflammatory cytokine production, and finally facilitate M1 polarization of macrophages which is closely associated with acute inflammatory responses in RAW264.7 cells (87).

Nucleotide-binding oligomerization domain 2 (Nod2) is a cytoplasmic human NOD-like receptor that recognizes bacterial components. Both wild-type Nod2 and a Nod2 Crohn's-associated variant are O-GlcNAcylated and this modification affects Nod2's ability to produce various inflammatory molecules such as cytokines and chemokines via $\mathrm{NF}-\kappa \mathrm{B}$ activation in $293 \mathrm{~T}$ cells (88).

\section{Anti-inflammatory role of O-GIcNAcylation}

In terms of cardiac and vasculature diseases, augmenting $\mathrm{O}-\mathrm{GlcNAc}$ modification of proteins in the vasculature may represent a novel anti-inflammatory and vasoprotective mechanism $(89,90)$. On one hand, acute GlcN and PUGNAc treatment increases $\mathrm{O}-\mathrm{GlcNAc}$-modified protein levels and ameliorates acute inflammatory responses in balloon-injured rat carotid arteries; a 14 -day $\mathrm{GlcN}$ treatment attenuates neointima formation (89). On the other hand, acute increases in protein $\mathrm{O}-\mathrm{GlcNAcylation}$ relieve $\mathrm{TNF}-\alpha$ triggered vascular dysfunction, at least partly, via mitigating the expression of iNOS (90). Furthermore, GlcN treatment and OGT overexpression attenuate the trauma-hemorrhage induced increase in cardiac levels of TNF- $\alpha$ and IL- 6 mRNA, I $\kappa$ B $\alpha$ phosphorylation, NF- $\kappa \mathrm{B}, \mathrm{NF}-\kappa \mathrm{B}$ DNA binding activity, ICAM-1, and myeloperoxidase activity. The enhanced O-GlcNAcylation triggered by both GlcN and OGT overexpression mediates improvement in cardiac function after hemorrhagic shock occurred $(91,92)$.

Negative regulation of the transcription factors by $O-G l c N A c y l a t i o n$. Aberrant regulation of NF- $\mathrm{NB}$ activity has been associated with a variety of disorders such as autoimmune disease, cancer and diabetes (93). Chronic inflammation is the main culprit of the diseases mentioned above (94-96). Therefore, fully elucidating the molecular mechanisms that precisely tune $\mathrm{NF}-\kappa \mathrm{B}$ activity may have great biological and clinical significance. Although increasing O-GlcNAc levels are usually accompanied by $\mathrm{NF}-\kappa \mathrm{B}$ activation in diabetes and insulin resistance, $\mathrm{O}-\mathrm{GlcNAcylation}$ inducing treatments appear to have anti-inflammatory and pro-survival effects during acute injuries like myocardial infarction, burns, trauma and sepsis $(91,92,97)$. For instance, GlcN or PUGNAc administration after trauma-hemorrhage improve organ perfusion and function, and this is associated with increased protein O-GlcNAc levels (91). Moreover, GlcN and PUGNAc treatment protect against $\mathrm{TNF}-\alpha$ induced inflammatory stress by enhancing O-GlcNAcylation at S536 of p65 and by inhibiting TNF- $\alpha$ induced phosphorylation of NF- $\kappa \mathrm{B}$ p65, thus inhibiting $\mathrm{NF}-\kappa \mathrm{B}$ signaling in rat aortic smooth muscle cells (98). In vivo, dextran sodium sulfate-induced NF- $\kappa \mathrm{B}$ p65 phosphorylation and IL-1 $\beta$ mRNA expression are significantly lower in Ogt-transgenic than in wild type mice. This suggests that O-GlcNAcylation could prevent acute colitis by reducing acute maximum inflammation (99).

Another study indicated that GlcN alleviates the O-GlcNAcylation of both nuclear and cytosolic forms of c-Rel and inhibits the binding of $c-R e l$ to the NF- $\kappa B$ site in the iNOS promoter upon stimulation by LPS. The mechanism by which GlcN exerts these effects involves the suppression of the interaction between c-Rel and OGT (100). Moreover, OGT plays a key role in the inflammatory responses of macrophages. It has been observed that in N9 microglial cells, in response to LPS, the enhanced expression of iNOS, NO and ROS is mediated via the downregulation of OGT and protein O-GlcNAcylation, or via the upregulation of MAPKs phosphorylation and $\mathrm{NF}-\kappa \mathrm{B}$ translocation (101). In addition, overexpression of OGT exhibits inhibitory effects on the LPS-driven activation of $\mathrm{NF}-\kappa \mathrm{B}$ and iNOS through modulation of histone acetylation 
either directly or indirectly (102). In addition to GlcN and OGT overexpression, thiamet $\mathrm{G}$, an OGA inhibitor, has been found to dramatically reduce the infarct volume and ameliorate the neurological deficits either before or after middle cerebral artery occlusion (MCAO). Moreover, thiamet G administration reduces the number of Iba1 ${ }^{+}$cells in MCAO mice and decreases the expression of iNOS and cyclooxygenase 2 mainly by suppressing NF- $\mathrm{KB}$ p65 pathway (103).

$\mathrm{Sp} 1$ is a zinc finger transcription factor. As described above, elevated Sp1 activity upon O-GlcNAcylation could play a role in hyperglycemia-induced pro-inflammatory and pro-fibrotic factors involved in diabetic retinopathy $(81,82)$. Alternatively, O-GlcNAc of Sp1 may also reduce its transcriptional activity, possibly by disturbing its interaction with its cooperative factors, such as Elf-1 (104), NF-Y (105), Ying-Yang 1 (106) and sterol regulatory element binding protein 2 (107). Thus, O-GlcNAc modification of $\mathrm{Spl}$ could be a participant in negative regulation of placental and embryonic expression of oncofetal protein gene (Pem) (104), hyaluronan synthesis (106) and lipid synthesis (107). Interestingly, Suh et al (108) and Lee et al (109) showed that O-GlcNAcylation of Sp1 protects against hypoxia-induced dysfunction of $\mathrm{Na}^{+} / \mathrm{glucose}$ cotransporter (SGLT) in renal proximal tubule cells and hypoxia-induced apoptosis of mouse embryonic stem cells. A weakening association between Sp1 and its co-operative factors caused by O-GlcNAcylated Sp1 could be a mechanism postulated to explain these phenomena.

Anti-inflammatory effects of other O-GlcNAcylated proteins. The zinc finger protein A20 (also known as TNFAIP3) has been identified as an inhibitory effector on NF- $\mathrm{\kappa B}$ over-activation by using its deubiquitinase activity (110). However, the regulation of A20 activity remains poorly understood. GlcN and thiamet G significantly increase A20 O-GlcNAcylation and enhance binding to Tax 1 binding protein 1 , a key regulatory protein for A20 activity. These data suggest that O-GlcNAcylation is a critical regulatory mechanism for A20 activity, which in turn negatively regulates the NF- $\kappa \mathrm{B}$ signaling cascade in TNF- $\alpha$ injured acute vascular smooth muscle cells (111).

Glutathione peroxidase 1 (GPX1), an anti-oxidant enzyme, is critical for cell survival during hyperglycemia and oxidative stress. Yang et al (112) discovered that hyperglycemia induces GPX1 activity by enhancing the O-GlcNAcylation of GPX1 and subsequently increases the association between non-receptor tyrosine kinase c-Abl and Arg in rat vascular smooth muscle cells. Also, pharmacological administration of the OGA inhibitor NTZ has been found to induce GPX1 activation in the mouse liver.

RNA polymerase II (RNAPII) catalyzes the transcription of all protein-coding genes and a number of non-coding RNAs. Hwang et al (65) discovered that GlcN relieves basal activities of transcription induced by LPS through the upregulation of RNAPII O-GlcNAcylation and DNA binding which are inhibited by LPS.

\section{Conclusions and future perspectives}

Since O-GlcNAcylation's involvement in various immune pathways appears complicated, the present review proposed several reasons why O-GlcNAcylation may exert different effects on inflammation and autoimmune diseases.
First, the O-GlcNAc modification as a dual-directional regulator of inflammation was discussed. On one hand, different stimuli lead to distinct outcomes, as exhibited by O-GlcNAcylation modifications in inflammatory responses. The key factor which determines the pro- or anti-inflammatory role of particular O-GlcNAcylation modifications is the type of insult (chronic hyperglycemia in diabetes vs. acute vascular injury). On the other hand, GlcN regulates inflammation by sensing energy states of normal and excess nutrients. At normal glucose concentrations, GlcN dose-dependently enhances LPS-triggered inflammation in macrophages. However, GlcN suppresses macrophage inflammation upon high glucose cell culture conditions. In addition, LPS-stimulates an increase in O-GlcNAcylation as well as an increase in DNA binding of c-Rel to the iNOS promoter by GlcN in normal glucose conditions, but a decrease in high glucose conditions (62). Moreover, hyperglycemia makes a pregnancy highly risky and may even have negative effects on the fetus. Since O-GlcNAcylation is believed to be a nutritionally responsive modification, it provides one means of explaining how excess nutrients in the intrauterine environment may affect metabolic deregulation of the offspring (113). Furthermore, GlcN-mediated O-GlcNAcylation participates in the inhibition of TNF- $\alpha$ and IL-8 gene expression in osteoarthritis (114). It therefore appears that, depending on the cellular nutrition state, the type of insult (chronic hyperglycemia in diabetes vs. acute vascular injury) and the cell state (inflammatory state vs. non-inflammatory state), HBP may quickly switch the management pattern to regulate inflammation, resulting in either pro- or anti-inflammatory outcomes (62). These results also suggest that O-GlcNAc may create a negative feedback loop between pro- and anti-inflammation. Thus, proper adjustment of O-GlcNAc presents a potential therapeutic strategy for combating metabolic dysregulation and inflammatory diseases such as diabetes, sepsis, and osteoarthritis.

Second, the present review considered O-GlcNAc as a target in relieving over-nutrition-related chronic inflammation and autoimmune diseases. The pathogenesis of obesity and type 2 diabetes are accompanied by long-term, low-grade, chronic inflammation. This inflammation has been implicated in much of the downstream pathology, including atherosclerosis, insulin resistance and a high risk for autoimmunity, which are associated with over-nutrition and adiposity $(115,116)$. In addition, disruption in the metabolic pathways of effector $\mathrm{T}$ cells is integral to the progress of atherosclerosis and insulin resistance, which may result in enhanced shunting of metabolites into the HBP, fueling O-GlcNAc modification. Moreover, effector T cells such as Th1 and Th17 cells are critical for a number of autoimmune diseases, including multiple sclerosis (MS), rheumatoid arthritis, inflammatory bowel disease, and systemic lupus erythematosus (SLE) (117). SLE presents a reactivation of the silenced $\mathrm{X}$-chromosome due to $\mathrm{CD} 4^{+} \mathrm{T}$ cell DNA demethylation and diet is thought to promote disease progression. The degree of overexpression of OGT in CD4 ${ }^{+}$ $\mathrm{T}$ cells could potentially contribute to SLE in women (118). Additionally, Th17 cells are likely the most critical pathogenic factor of human MS. It was shown that miR-15b suppressed Th17 differentiation and the pathogenesis of MS by decreasing OGT expression in an NF- $\kappa \mathrm{B}$ p65- and c-Rel-dependent manner (119). Thus, these observations logically led to the 
investigation of the link between O-GlcNAcylation of proteins and $\mathrm{T}$ cell activation that are involved in metabolic and autoimmune diseases. Further characterization of the role of OGT and O-GlcNAc in autoimmunity may suggest new therapeutic targets for autoimmune diseases. Collectively, the recent explosion of research in this field indicates that the mechanisms by which O-GlcNAcylation regulates immune and inflammation responses will soon become clear.

\section{Acknowledgements}

Not applicable.

\section{Funding}

The present review was supported by the National Natural Science Foundation of China (grant no. 81700726), the Doctoral Starting Grant of Liaoning Province (grant no. 20170520401) and the Dalian Medical Science Research Program (grant no. 1712006) to Y.L. The present review was also supported by the National Natural Science Foundation of China [XM (grant no. 81603428), JD (grant no. 81570727) and LM (grant no. 81700747$)]$.

\section{Availability of data and materials}

Not applicable.

\section{Authors' contributions}

YL and JD contributed to the conception of the study, wrote the manuscript, performed the literature search and prepared the original draft preparation. YL wrote, reviewed and edited the manuscript. MX and LM performed the literature search and constructed the figures. All the authors have read and approved the final manuscript.

\section{Ethics approval and consent to participate}

Not applicable.

\section{Patient consent for publication}

Not applicable.

\section{Competing interests}

The authors declare that they have no competing interests.

\section{References}

1. Ong Q, Han W and Yang X: O-GlcNAc as an integrator of signaling pathways. Front Endocrinol (Lausanne) 9: 599, 2018.

2. D'Hondt C, Iyyathurai J, Vinken M, Rogiers V, Leybaert L, Himpens B and Bultynck G: Regulation of connexin- and pannexin-based channels by post-translational modifications. Biol Cell 105: 373-398, 2013.

3. Xie Y, Kang R, Sun X, Zhong M, Huang J, Klionsky DJ and Tang D: Posttranslational modification of autophagy-related proteins in macroautophagy. Autophagy 11: 28-45, 2015.

4. Schedin-Weiss S, Winblad B and Tjernberg LO: The role of protein glycosylation in Alzheimer disease. FEBS J 281: 46-62, 2014.
5. Gurel Z and Sheibani N: O-Linked $\beta$-N-acetylglucosamine (O-GlcNAc) modification: A new pathway to decode pathogenesis of diabetic retinopathy. Clin Sci (Lond) 132: 185-198, 2018.

6. Hurtado-Guerrero R, Dorfmueller HC and van Aalten DM: Molecular mechanisms of O-GlcNAcylation. Curr Opin Struct Biol 18: 551-557, 2008.

7. Yang X and Qian K: Protein O-GlcNAcylation: Emerging mechanisms and functions. Nat Rev Mol Cell Biol 18: 452-465, 2017.

8. Myslicki JP, Belke DD and Shearer J: Role of O-GlcNAcylation in nutritional sensing, insulin resistance and in mediating the benefits of exercise. Appl Physiol Nutr Metab 39: 1205-1213, 2014.

9. Levine ZG and Walker S: The biochemistry of O-GlcNAc transferase: Which functions make it essential in mammalian cells? Annu Rev Biochem 85: 631-657, 2016.

10. Aquino-Gil M, Pierce A, Perez-Cervera Y, Zenteno E and Lefebvre T: OGT: A short overview of an enzyme standing out from usual glycosyltransferases. Biochem Soc Trans 45: 365-370, 2017.

11. Ogawa M, Furukawa K and Okajima T: Extracellular O-linked $\beta$-N-acetylglucosamine: Its biology and relationship to human disease. World J Biol Chem 5: 224-230, 2014.

12. Varshney S and Stanley P: EOGT and O-GlcNAc on secreted and membrane proteins. Biochem Soc Trans 45: 401-408, 2017.

13. Ruan HB, Nie Y and Yang X: Regulation of protein degradation by O-GlcNAcylation: Crosstalk with ubiquitination. Mol Cell Proteomics 12: 3489-3497, 2013.

14. Zhu Y, Liu TW, Cecioni S, Eskandari R, Zandberg WF and Vocadlo DJ: O-GlcNAc occurs cotranslationally to stabilize nascent polypeptide chains. Nat Chem Biol 11: 319-325, 2015.

15. Sayat R, Leber B, Grubac V, Wiltshire L and Persad S: O-GlcNAc-glycosylation of beta-catenin regulates its nuclear localization and transcriptional activity. Exp Cell Res 314: 2774-2787, 2008.

16. Skorobogatko Y, Landicho A, Chalkley RJ, Kossenkov AV, Gallo $\mathrm{G}$ and Vosseller K: O-linked $\beta$ - $\mathrm{N}$-acetylglucosamine (O-GlcNAc) site thr-87 regulates synapsin I localization to synapses and size of the reserve pool of synaptic vesicles. J Biol Chem 289: 3602-3612, 2014.

17. Butkinaree C, Park K and Hart GW: O-linked beta-N-acetylglucosamine (O-GlcNAc): Extensive crosstalk with phosphorylation to regulate signaling and transcription in response to nutrients and stress. Biochim Biophys Acta 1800: 96-106, 2010.

18. Levine ZG, Fan C, Melicher MS, Orman M, Benjamin T and Walker S: O-GlcNAc transferase recognizes protein substrates using an asparagine ladder in the tetratricopeptide repeat (TPR) superhelix. J Am Chem Soc 140: 3510-3513, 2018.

19. Rafie K, Raimi O, Ferenbach AT, Borodkin VS, Kapuria V and van Aalten DMF: Recognition of a glycosylation substrate by the O-GlcNAc transferase TPR repeats. Open Biol 7: 170078, 2017.

20. Ma X, Liu P, Yan H, Sun H, Liu X, Zhou F, Li L, Chen Y, Muthana MM, Chen X, et al: Substrate specificity provides insights into the sugar donor recognition mechanism of O-GlcNAc transferase (OGT). PLoS One 8: e63452, 2013.

21. Nagel AK and Ball LE: O-GlcNAc transferase and O-GlcNAcase: Achieving target substrate specificity. Amino Acids 46: 2305-2316, 2014.

22. Bullen JW, Balsbaugh JL, Chanda D, Shabanowitz J, Hunt DF, Neumann D and Hart GW: Cross-talk between two essential nutrient-sensitive enzymes: O-GlcNAc transferase (OGT) and AMP-activated protein kinase (AMPK). J Biol Chem 289: 10592-10606, 2014.

23. Watson LJ, Long BW, DeMartino AM, Brittian KR, Readnower RD, Brainard RE, Cummins TD, Annamalai L, Hill BG and Jones SP: Cardiomyocyte Ogt is essential for postnatal viability. Am J Physiol Heart Circ Physiol 306: H142-H153, 2014.

24. Ortiz-Meoz RF, Jiang J, Lazarus MB, Orman M, Janetzko J, Fan C, Duveau DY, Tan ZW, Thomas CJ and Walker S: A small molecule that inhibits OGT activity in cells. ACS Chem Biol 10: 1392-1397, 2015.

25. Gross BJ, Kraybill BC and Walker S: Discovery of O-GlcNAc transferase inhibitors. J Am Chem Soc 127: 14588-14589, 2005.

26. Jiang J, Lazarus MB, Pasquina L, Sliz P and Walker S: A neutral diphosphate mimic crosslinks the active site of human O-GlcNAc transferase. Nat Chem Biol 8: 72-77, 2011.

27. Borodkin VS, Schimpl M, Gundogdu M, Rafie K, Dorfmueller HC, Robinson DA and van Aalten DM: Bisubstrate UDP-peptide conjugates as human O-GlcNAc transferase inhibitors. Biochem J 457: 497-502, 2014. 
28. Trapannone R, Rafie K and van Aalten DM: O-GlcNAc transferase inhibitors: Current tools and future challenges. Biochem Soc Trans 44: 88-93, 2016.

29. Ruan HB, Singh JP, Li MD, Wu J and Yang X: Cracking the O-GlcNAc code in metabolism. Trends Endocrinol Metab 24: 301-309, 2013

30. Hanover JA, Krause MW and Love DC: Bittersweet memories: Linking metabolism to epigenetics through O-GlcNAcylation. Nat Rev Mol Cell Biol 13: 312-321, 2012.

31. He Y, Roth C, Turkenburg JP and Davies GJ: Three-dimensional structure of a Streptomyces sviceus GNAT acetyltransferase with similarity to the C-terminal domain of the human GH84 O-GlcNAcase. Acta Crystallogr D Biol Crystallogr 70: 186-195, 2014.

32. Elsen NL, Patel SB, Ford RE, Hall DL, Hess F, Kandula H, Kornienko M, Reid J, Selnick H, Shipman JM, et al: Insights into activity and inhibition from the crystal structure of human O-GlcNAcase. Nat Chem Biol 13: 613-615, 2017.

33. Keembiyehetty CN, Krzeslak A, Love DC and Hanover JA: A lipid-droplet-targeted O-GlcNAcase isoform is a key regulator of the proteasome. J Cell Sci 124: 2851-2860, 2011.

34. Khidekel N, Ficarro SB, Clark PM, Bryan MC, Swaney DL, Rexach JE, Sun YE, Coon JJ, Peters EC and Hsieh-Wilson LC: Probing the dynamics of O-GlcNAc glycosylation in the brain using quantitative proteomics. Nat Chem Biol 3: 339-348, 2007.

35. Crotty S: Follicular helper CD4 T cells (TFH). Annu Rev Immunol 29: 621-663, 2011.

36. Wang R, Dillon CP, Shi LZ, Milasta S, Carter R, Finkelstein D, McCormick LL, Fitzgerald P, Chi H, Munger J and Green DR: The transcription factor Myc controls metabolic reprogramming upon T lymphocyte activation. Immunity 35: 871-882, 2011.

37. MacIver NJ, Michalek RD and Rathmell JC: Metabolic regulation of T lymphocytes. Annu Rev Immunol 31: 259-283, 2013.

38. Machacek M, Slawson C and Fields PE: O-GlcNAc: A nove regulator of immunometabolism. J Bioenerg Biomembr 50 : 223-229, 2018.

39. Woo CM, Lund PJ, Huang AC, Davis MM, Bertozzi CR and Pitteri SJ: Mapping and quantification of over 2,000 O-linked glycopeptides in activated human T cells with isotope-targeted glycoproteomics (IsoTaG). Mol Cell Proteomics 17: 764-775, 2018.

40. Lund PJ, Elias JE and Davis MM: Global analysis of O-GlcNAc glycoproteins in activated human T cells. J Immunol 197: 3086-3098, 2016.

41. Swamy M, Pathak S, Grzes KM, Damerow S, Sinclair LV, van Aalten DM and Cantrell DA: Glucose and glutamine fuel protein $\mathrm{O}-$ GlcNAcylation to control $\mathrm{T}$ cell self-renewal and malignancy. Nat Immunol 17: 712-720, 2016.

42. Hao X, Li Y, Wang J, Ma J, Zhao S, Ye X, He L, Yang J, Gao M, Xiao F and Wei H: Deficient O-GlcNAc glycosylation impairs regulatory $\mathrm{T}$ cell differentiation and notch signaling in autoimmune hepatitis. Front Immunol 9: 2089, 2018.

43. Ghosh S, May MJ and Kopp EB: NF-kappa B and Rel proteins: Evolutionarily conserved mediators of immune responses. Annu Rev Immunol 16: 225-260, 1998.

44. Karin M and Ben-Neriah Y: Phosphorylation meets ubiquitination: The control of NF-[kappa]B activity. Annu Rev Immunol 18 621-663, 2000

45. Lecoq L, Raiola L, Chabot PR, Cyr N, Arseneault G, Legault P and Omichinski JG: Structural characterization of interactions between transactivation domain 1 of the p65 subunit of NF- $\kappa \mathrm{B}$ and transcription regulatory factors. Nucleic Acids Res 45: 5564-5576, 2017

46. Yi H, Peng R, Zhang LY, Sun Y, Peng HM, Liu HD, Yu LJ, Li AL, Zhang YJ, Jiang WH and Zhang Z: LincRNA-Gm4419 knockdown ameliorates NF- $\kappa \mathrm{B} / \mathrm{NLRP} 3$ inflammasome-mediated inflammation in diabetic nephropathy. Cell Death Dis 8: e2583, 2017.

47. Grundy SM: Overnutrition, ectopic lipid and the metabolic syndrome. J Investig Med 64: 1082-1086, 2016.

48. Zhang Q, Lenardo MJ and Baltimore D: 30 years of NF- $\kappa$ B: A blossoming of relevance to human pathobiology. Cell 168: 37-57, 2017.

49. Baker RG, Hayden MS and Ghosh S: NF- $\kappa B$, inflammation, and metabolic disease. Cell Metab 13: 11-22, 2011.

50. Hayes JB, Sircy LM, Heusinkveld LE, Ding W, Leander RN, McClelland EE and Nelson DE: Modulation of macrophage inflammatory nuclear factor $\kappa \mathrm{B}(\mathrm{NF}-\kappa \mathrm{B})$ signaling by intracellular cryptococcus neoformans. J Biol Chem 291: 15614-15627, 2016
51. Esser N, Paquot N and Scheen AJ: Anti-inflammatory agents to treat or prevent type 2 diabetes, metabolic syndrome and cardiovascular disease. Expert Opin Investig Drugs 24: 283-307, 2015.

52. Golks A, Tran TT, Goetschy JF and Guerini D: Requirement for O-linked $\mathrm{N}$-acetylglucosaminyltransferase in lymphocytes activation. EMBO J 26: 4368-4379, 2007.

53. Bunting K, Rao S, Hardy K, Woltring D, Denyer GS, Wang J, Gerondakis S and Shannon MF: Genome-wide analysis of gene expression in T cells to identify targets of the NF-kappa B transcription factor c-Rel. J Immunol 178: 7097-7109, 2007.

54. Ramakrishnan P, Clark PM, Mason DE, Peters EC, HsiehWilson LC and Baltimore D: Activation of the transcriptional function of the NF- $\kappa$ B protein c-Rel by O-GlcNAc glycosylation. Sci Signal 6: ra75, 2013 .

55. Baudoin L and Issad T: O-GlcNacylation and inflammation: A vast territory to explore. Front Endocrinol (Lausanne) 5: 235, 2014.

56. Wu JL, Chiang MF, Hsu PH, Tsai DY, Hung KH, Wang YH, Angata T and Lin KI: O-GlcNAcylation is required for B cell homeostasis and antibody responses. Nat Commun 8: 1854, 2017.

57. Zanni MV, Burdo TH, Makimura H, Williams KC and Grinspoon SK: Relationship between monocyte/macrophage activation marker soluble CD163 and insulin resistance in obese and normal-weight subjects. Clin Endocrinol (Oxf) 77: 385-390, 2012.

58. Nagareddy PR, Kraakman M, Masters SL, Stirzaker RA, Gorman DJ, Grant RW, Dragoljevic D, Hong ES, Abdel-Latif A, Smyth SS, et al: Adipose tissue macrophages promote myelopoiesis and monocytosis in obesity. Cell Metab 19: 821-835, 2014.

59. Mauldin JP, Nagelin MH, Wojcik AJ, Srinivasan S, Skaflen MD, Ayers CR, McNamara CA and Hedrick CC: Reduced expression of ATP-binding cassette transporter G1 increases cholesterol accumulation in macrophages of patients with type 2 diabetes mellitus. Circulation 117: 2785-2792, 2008

60. Westerbacka J, Kolak M, Kiviluoto T, Arkkila P, Sirén J, Hamsten A, Fisher RM and Yki-Järvinen H: Genes involved in fatty acid partitioning and binding, lipolysis, monocyte/macrophage recruitment, and inflammation are overexpressed in the human fatty liver of insulin-resistant subjects. Diabetes 56: 2759-2765, 2007

61. Vasamsetti SB, Karnewar S, Kanugula AK, Thatipalli AR, Kumar JM and Kotamraju S: Metformin inhibits monocyte-to-macrophage differentiation via AMPK-mediated inhibition of STAT3 activation: Potential role in atherosclerosis. Diabetes 64: 2028-2041, 2015.

62. Hwang JS, Kwon MY, Kim KH, Lee Y, Lyoo IK, Kim JE, Oh ES and Han IO: Lipopolysaccharide (LPS)-stimulated iNOS induction is increased by glucosamine under normal glucose conditions but is inhibited by glucosamine under high glucose conditions in macrophage cells. J Biol Chem 292: 1724-1736, 2017.

63. Ryu IH and Do SI: Denitrosylation of S-nitrosylated OGT is triggered in LPS-stimulated innate immune response. Biochem Biophys Res Commun 408: 52-57, 2011

64. Hwang SY, Shin JH, Hwang JS, Kim SY, Shin JA, Oh ES, Oh S, Kim JB, Lee JK and Han IO: Glucosamine exerts a neuroprotective effect via suppression of inflammation in rat brain ischemia/reperfusion injury. Glia 58: 1881-1892, 2010.

65. Hwang JS, Hwang SY and Han IO: Basal transcription is regulated by lipopolysaccharide and glucosamine via the regulation of DNA binding of RNA polymerase II in RAW264.7 cells. Life Sci 110: 93-98, 2014.

66. Kneass ZT and Marchase RB: Protein O-GlcNAc modulates motility-associated signaling intermediates in neutrophils. J Biol Chem 280: 14579-14585, 2005.

67. Kneass ZT and Marchase RB: Neutrophils exhibit rapid agonist-induced increases in protein-associated O-GlcNAc. J Biol Chem 279: 45759-45765, 2004.

68. Madsen-Bouterse SA, Xu Y, Petty HR and Romero R: Quantification of O-GlcNAc protein modification in neutrophils by flow cytometry. Cytometry A 73: 667-672, 2008.

69. Hart GW, Slawson C, Ramirez-Correa G and Lagerlof O: Cross talk between O-GlcNAcylation and phosphorylation: Roles in signaling, transcription, and chronic disease. Annu Rev Biochem 80: 825-858, 2011

70. Ma $\mathrm{J}$ and Hart GW: O-GlcNAc profiling: From proteins to proteomes. Clin Proteomics 11: 8, 2014

71. Krick S, Helton ES, Hutcheson SB, Blumhof S, Garth JM, Denson RS, Zaharias RS, Wickham H and Barnes JW: FGF23 Induction of O-linked $\mathrm{N}$-acetylglucosamine regulates IL-6 secretion in human bronchial epithelial cells. Front Endocrinol (Lausanne) 9: 708, 2018. 
72. Guo X, Shang J, Deng Y, Yuan X, Zhu D and Liu H: Alterations in left ventricular function during intermittent hypoxia: Possible involvement of $\mathrm{O}-\mathrm{GlcNAc}$ protein and MAPK signaling. Int J Mol Med 36: 150-158, 2015.

73. James LR, Tang D, Ingram A, Ly H, Thai K, Cai L and Scholey JW: Flux through the hexosamine pathway is a determinant of nuclear factor kappaB- dependent promoter activation. Diabetes 51: 1146-1156, 2002

74. Dela Justina V, Goncalves JS, de Freitas RA, Fonseca AD, Volpato GT, Tostes RC, Carneiro FS, Lima VV and Giachini FR Increased $\mathrm{O}$-linked $\mathrm{N}$-acetylglucosamine modification of $\mathrm{NF}-\kappa \mathrm{B}$ and augmented cytokine production in the placentas from hyperglycemic rats. Inflammation 40: 1773-1781, 2017.

75. Zhang D, Cai Y, Chen M, Gao L, Shen Y and Huang Z: OGT-mediated O-GlcNAcylation promotes NF- $\kappa$ B activation and inflammation in acute pancreatitis. Inflamm Res 64: 943-952, 2015.

76. Li Y, Liu H, Xu QS, Du YG and Xu J: Chitosan oligosaccharides block LPS-induced O-GlcNAcylation of NF- $\kappa \mathrm{B}$ and endothelial inflammatory response. Carbohydr Polym 99: 568-578, 2014.

77. Yang WH, Park SY, Nam HW, Kim DH, Kang JG, Kang ES Kim YS, Lee HC, Kim KS and Cho JW: NFkappaB activation is associated with its O-GlcNAcylation state under hyperglycemic conditions. Proc Natl Acad Sci USA 105: 17345-17350, 2008.

78. Allison DF, Wamsley JJ, Kumar M, Li D, Gray LG, Hart GW Jones DR and Mayo MW: Modification of RelA by O-linked $\mathrm{N}$-acetylglucosamine links glucose metabolism to $\mathrm{NF}-\kappa \mathrm{B}$ acetylation and transcription. Proc Natl Acad Sci USA 109: 16888-16893, 2012.

79. Ma Z, Chalkley RJ and Vosseller K: Hyper-O-GlcNAcylation activates nuclear factor $\kappa$-light-chain-enhancer of activated $B$ cells $(\mathrm{NF}-\kappa \mathrm{B})$ signaling through interplay with phosphorylation and acetylation. J Biol Chem 292: 9150-9163, 2017.

80. Kawauchi K, Araki K, Tobiume K and Tanaka N: Loss of p53 enhances catalytic activity of IKKbeta through O-linked beta-N-acetyl glucosamine modification. Proc Natl Acad Sci USA 106: 3431-3436, 2009.

81. Donovan K, Alekseev O, Qi X, Cho W and Azizkhan-Clifford J: O-GlcNAc modification of transcription factor Sp1 mediates hyperglycemia-induced VEGF-A upregulation in retinal cells. Invest Ophthalmol Vis Sci 55: 7862-7873, 2014

82. Zhang Y, Qu Y,Niu T, Wang H and Liu K: O-GlcNAc modification of Sp1 mediates hyperglycaemia-induced ICAM-1 up-regulation in endothelial cells. Biochem Biophys Res Commun 484: 79-84, 2017.

83. O'Shea JJ and Plenge R: JAK and STAT signaling molecules in immunoregulation and immune-mediated disease. Immunity 36 $542-550,2012$

84.Li X, Zhang Z, Li L, Gong W, Lazenby AJ, Swanson BJ, Herring LE, Asara JM, Singer JD and Wen H: Myeloid-derived cullin 3 promotes STAT3 phosphorylation by inhibiting OGT expression and protects against intestinal inflammation. J Exp Med 214: 1093-1109, 2017.

85. Pathak S, Borodkin VS, Albarbarawi O, Campbell DG Ibrahim A and van Aalten DM: O-GlcNAcylation of TAB1 modulates TAK1-mediated cytokine release. EMBO J 31: 1394-1404, 2012.

86. Hirata Y,Takahashi M,Morishita T, Noguchi T and Matsuzawa A: Post-translational modifications of the TAK1-TAB complex. Int J Mol Sci 18: E205, 2017.

87. Zhang D, Xu Z, Tao T, Liu X, Sun X, Ji Y, Han L, Qiu H Zhu G, Shen Y, et al: Modification of TAK1 by O-linked $\mathrm{N}$-acetylglucosamine facilitates TAK1 activation and promotes M1 macrophage polarization. Cell Signal 28: 1742-1752, 2016.

88. Hou CW, Mohanan V, Zachara NE and Grimes CL: Identification and biological consequences of the O-GlcNAc modification of the human innate immune receptor, Nod2. Glycobiology 26: $13-18,2016$.

89. Xing D, Feng W, Not LG, Miller AP, Zhang Y, Chen YF, Majid-Hassan E, Chatham JC and Oparil S: Increased protein O-GlcNAc modification inhibits inflammatory and neointimal responses to acute endoluminal arterial injury. Am J Physiol Heart Circ Physiol 295: H335-H342, 2008.

90. Hilgers RH, Xing D, Gong K, Chen YF, Chatham JC and Oparil S: Acute O-GlcNAcylation prevents inflammation-induced vascular dysfunction. Am J Physiol Heart Circ Physiol 303: H513-H522, 2012

91. Zou L, Yang S, Hu S, Chaudry IH, Marchase RB and Chatham JC: The protective effects of PUGNAc on cardiac function after trauma-hemorrhage are mediated via increased protein O-GlcNAc levels. Shock 27: 402-408, 2007.
92.Zou L, Yang S, Champattanachai V, Hu S, Chaudry IH, Marchase RB and Chatham JC: Glucosamine improves cardiac function following trauma-hemorrhage by increased protein O-GlcNAcylation and attenuation of NF- $\{$ kappa $\}$ B signaling. Am J Physiol Heart Circ Physiol 296: H515-H523, 2009.

93. Yamamoto Y and Gaynor RB: IkappaB kinases: Key regulators of the NF-kappaB pathway. Trends Biochem Sci 29: 72-79, 2004

94. Meirow Y and Baniyash M: Immune biomarkers for chronic inflammation related complications in non-cancerous and cancerous diseases. Cancer Immunol Immunother 66: 1089-1101, 2017.

95. Holmdahl R, Sareila O, Olsson LM, Backdahl L and Wing K: Ncf1 polymorphism reveals oxidative regulation of autoimmune chronic inflammation. Immunol Rev 269: 228-247, 2016.

96. Pietropaolo M, Barinas-Mitchell E and Kuller LH: The heterogeneity of diabetes: Unraveling a dispute: Is systemic inflammation related to islet autoimmunity? Diabetes 56: 1189-1197, 2007.

97. Vaidyanathan K and Wells L: Multiple tissue-specific roles for the O-GlcNAc post-translational modification in the induction of and complications arising from type II diabetes. J Biol Chem 289: 34466-34471, 2014.

98. Xing D, Gong K, Feng W, Nozell SE, Chen YF, Chatham JC and Oparil S: O-GlcNAc modification of NFкB p65 inhibits $\mathrm{TNF}-\alpha$-induced inflammatory mediator expression in rat aortic smooth muscle cells. PLoS One 6: e24021, 2011.

99. Hirata Y, Nakagawa T, Moriwaki K, Koubayashi E, Kakimoto K, Takeuchi T, Inoue T, Higuchi K and Asahi M: Augmented O-GlcNAcylation alleviates inflammation-mediated colon carcinogenesis via suppression of acute inflammation. J Clin Biochem Nutr 62: 221-229, 2018.

100. Hwang SY, Hwang JS, Kim SY and Han IO: O-GlcNAcylation and $\mathrm{p} 50 / \mathrm{p} 105$ binding of c-Rel are dynamically regulated by LPS and glucosamine in BV2 microglia cells. Br J Pharmacol 169: 1551-1560, 2013

101. Zheng GM, Yu C and Yang Z: Puerarin suppresses production of nitric oxide and inducible nitric oxide synthase in lipopolysaccharide-induced N9 microglial cells through regulating MAPK phosphorylation, O-GlcNAcylation and NF- $\kappa \mathrm{B}$ translocation. Int J Oncol 40: 1610-1618, 2012.

102. Hwang SY, Hwang JS, Kim SY and Han IO: O-GlcNAc transferase inhibits LPS-mediated expression of inducible nitric oxide synthase through an increased interaction with $\mathrm{mSin} 3 \mathrm{~A}$ in RAW264.7 cells. Am J Physiol Cell Physiol 305: C601-C608, 2013.

103. He Y, Ma X, Li D and Hao J: Thiamet G mediates neuroprotection in experimental stroke by modulating microglia/macrophage polarization and inhibiting NF- $\kappa \mathrm{B}$ p65 signaling. J Cereb Blood Flow Metab 37: 2938-2951, 2017.

104. Lim K and Chang HI: O-GlcNAc inhibits interaction between Sp1 and Elf-1 transcription factors. Biochem Biophys Res Commun 380: 569-574, 2009.

105. Lim K and Chang HI: O-GlcNAcylation of Sp1 interrupts Sp1 interaction with NF-Y. Biochem Biophys Res Commun 382 593-597, 2009

106. Jokela TA, Makkonen KM, Oikari S, Kärnä R, Koli E, Hart GW Tammi RH, Carlberg C and Tammi MI: Cellular content of UDP-N-acetylhexosamines controls hyaluronan synthase 2 expression and correlates with $\mathrm{O}$-linked $\mathrm{N}$-acetylglucosamine modification of transcription factors YY1 and SP1. J Biol Chem 286: 33632-33640, 2011

107. Lim K and Chang HI: O-GlcNAc inhibits interaction between $\mathrm{Spl}$ and sterol regulatory element binding protein 2 . Biochem Biophys Res Commun 393: 314-318, 2010.

108. Suh HN, Lee YJ, Kim MO, Ryu JM and Han HJ: Glucosamineinduced Sp1 O-GlcNAcylation ameliorates hypoxia-induced SGLT dysfunction in primary cultured renal proximal tubule cells. J Cell Physiol 229: 1557-1568, 2014.

109. Lee HJ, Ryu JM, Jung YH, Lee KH, Kim DI and Han HJ: Glycerol-3-phosphate acyltransferase-1 upregulation by O-GlcNAcylation of Sp1 protects against hypoxia-induced mouse embryonic stem cell apoptosis via mTOR activation. Cell Death Dis 7: e2158, 2016.

110. Coornaert B, Carpentier I and Beyaert R: A20: Central gatekeeper in inflammation and immunity. J Biol Chem 284: 8217-8221, 2009.

111. Yao D, Xu L, Xu O, Li R, Chen M, Shen H, Zhu H, Zhang F, Yao D, Chen YF, et al: O-Linked $\beta$-N-acetylglucosamine modification of A20 enhances the inhibition of NF- $\kappa$ B (nuclear factor- $\kappa$ B) activation and elicits vascular protection after acute endoluminal arterial injury. Arterioscler Thromb Vasc Biol 38: 1309-1320, 2018. 
112. Yang WH, Park SY, Ji S, Kang JG, Kim JE, Song H, Mook-Jung I, Choe KM and Cho JW: O-GlcNAcylation regulates hyperglycemia-induced GPX1 activation. Biochem Biophys Res Commun 391: 756-761, 2010.

113. Olivier-Van Stichelen S and Hanover JA: You are what you eat: O-linked $\mathrm{N}$-acetylglucosamine in disease, development and epigenetics. Curr Opin Clin Nutr Metab Care 18: 339-345, 2015.

114. Someya A,Ikegami T, Sakamoto K and Nagaoka I: Glucosamine downregulates the IL-1 $\beta$-induced expression of proinflammatory cytokine genes in human synovial MH7A cells by O-GlcNAc modification-dependent and -independent mechanisms. PLoS One 11: e0165158, 2016.

115. Chehimi M, Vidal $\mathrm{H}$ and Eljaafari A: Pathogenic role of IL-17-producing immune cells in obesity, and related inflammatory diseases. J Clin Med 6: E68, 2017.

116. Ridker PM, Everett BM, Thuren T, MacFadyen JG, Chang WH, Ballantyne C, Fonseca F, Nicolau J, Koenig W, Anker SD, et al: Antiinflammatory therapy with canakinumab for atherosclerotic disease. N Engl J Med 377: 1119-1131, 2017.

117. Carbo A, Hontecillas R, Kronsteiner B, Viladomiu M, Pedragosa M, Lu P, Philipson CW, Hoops S, Marathe M, Eubank S, et al: Systems modeling of molecular mechanisms controlling cytokine-driven $\mathrm{CD} 4^{+} \mathrm{T}$ cell differentiation and phenotype plasticity. PLoS Comput Biol 9: e1003027, 2013.
118. Hewagama A, Gorelik G, Patel D, Liyanarachchi P, McCune WJ Somers E, Gonzalez-Rivera T, Michigan Lupus Cohort, Strickland F and Richardson B: Overexpression of X-linked genes in $\mathrm{T}$ cells from women with lupus. J Autoimmun 41: 60-71, 2013

119. Liu R, Ma X, Chen L, Yang Y, Zeng Y, Gao J, Jiang W, Zhang F, Li D, Han B, et al: MicroRNA-15b suppresses Th17 differentiation and is associated with pathogenesis of multiple sclerosis by targeting O-GlcNAc transferase. J Immunol 198: 2626-2639, 2017.

This work is licensed under a Creative Commons Attribution-NonCommercial-NoDerivatives 4.0 International (CC BY-NC-ND 4.0) License. 